\title{
Ice Loads Impact on Spillway Culverts Piers in Lithuania
}

\author{
Raimondas ŠADZEVIČIUS*, Tatjana SANKAUSKIENË** \\ *Institute of Hydraulic Engineering, Universiteto 10, LT-53361 Akademija, Kaunas distr., Lithuania, \\ E-mail: raimondas.sadzevicius@asu.lt \\ **Institute of Hydraulic Engineering, Universiteto 10, LT-53361 Akademija, Kaunas distr., Lithuania, \\ E-mail: tatjana.sankauskiene@asu.lt
}

cross $^{\text {ref }}$ http://dx.doi.org/10.5755/j01.mech.24.3.21067

\section{Introduction}

Reinforced concrete pier technical state and durability are determined by their impact and loads due to aggressive climatic and aquatic environmental factors. They are worn due to the abovementioned factors, and damage is caused, and when designing the piers, most of the loads generated by waves, ice and water are taken into account. Constructively, the upper front part of the pier is directed downstream and performs the starling's functions. This work is focusing to the evaluation of the influence of ice loads on pier structures. According to the Construction Technical Regulation (CTR) [1], the following types of ice loads are assessed:

- loads of moving ice fields on structures;

- loads occurring due to the temperature expansion of the continuous ice cover;

- ice jamming loads on structures;

- frozen to the structure ice cover loads with the change in water level.

Under Lithuanian conditions, the impact of ice on reinforced concrete pier structures has been little studied, but the influence of ice on structures has been studied by a number of foreign scientists. Scientists from Finland [2], Sweden [3], Japan [4], Spain [5], United States of America [6] and others studied the ice load on a vertical structure, but these works focus on the formation of sea ice. The detailed ice decomposition mechanics, ice load models (continuum, stochastic, discrete), degradation mechanisms are described in detail in literature [7].

Probabilistic modelling of the ice load can be accomplished using the ANCHORED STRUCTURES software package. This computer program simulates ice parameters in accordance with deterministic methods of calculating ice loads and the normative documents of different countries. Probabilistic parameter distribution laws are assumed to be constant, but the parameters themselves are modelled by the Monte-Carlo method and vary with different intensities. The probabilistic modelling results are presented in the probability amplitudes of ice loads, according to which the maximum loads that are repeated with a certain probability are calculated; it is also possible to determine the fatigue effect of the structure. This software suite is more about modelling the sea ice formation process and calculating the impact of ice on coastal structures.

Since sea ice is characterized by a higher salinity, its properties are different from ice generated in freshwater bodies, therefore it is impossible to refer to the work of these foreign researchers in calculating ice loads in Lithuanian ponds. Analytical calculations of ice loads based on different countries, such as Russia, Canada, Finland, America's normative documents and their comparison according to Lithuanian normative documents were carried out by $\mathrm{R}$. Šadzevičius [8] and E. Belozaras [9]. The calculation methods described above are more relevant in cold climates, and in Lithuanian conditions, where the winter is softer, it would be relevant to solve issues of ice formation, degradation and load calculations based on special observations that are not specially carried out in Lithuania.

According to the analysis of the reviewed literature, it has been established that the influence of ice loads on the reinforced concrete structures of piers has not been sufficiently estimated in the scientific literature.

The aim of the work is to evaluate the ice loads formed in Lithuanian ponds and their influence on the reinforced concrete structures of hydro systems' piers.

\section{Testing procedures}

There were investigated reinforced concrete structures of piers in 6 dams located in Marijampolè and Kèdainiai districts. For more detailed research, piers of Antanavas, Netičkampis and Marijampolè Lagoon, Marijampolè city (Marijampolè district), Dotnuva - Akademija and Kruostas (Kèdainiai district), deterioration character of which allows to assert that they were destroyed under the influence of ice loads, were chosen. The structures were visually examined on location and their most deteriorated places were established. The depths of the biggest selected 3-6 pittings were measured by a sliding gauge with the accuracy of $0.1 \mathrm{~mm}$. Knowing actual functioning period of a structure, the average depth of pittings was established as well as the average deepening speed of a pitting in a structure $v$ ( $\mathrm{mm}$ per year).

In the case of field investigations, the most damaged structures, the type of damage and the main research characteristic - compressive strength of concrete have been determined. The technical state of the piers of studied ponds was evaluated by the points in accordance with the methodology given in the CTR [10].

Non-destructive compressive strength tests were carried out according to European Standard [11] using a calibrated device - a Schmidt hammer (made by the Swiss company Proceq, factory No. N-34 160752), which was tested before and after the test on the reference forefront. Test sites were prepared using abrasive stone.

Laboratory tests to determine ice strength were carried out. The test samples were made by cutting the ice cubes with a saw, forming equal cubes of $15 \times 15 \times 15 \mathrm{~cm}$, to measure, weigh and crush using the press Controls MCC8 (Fig. 1). 


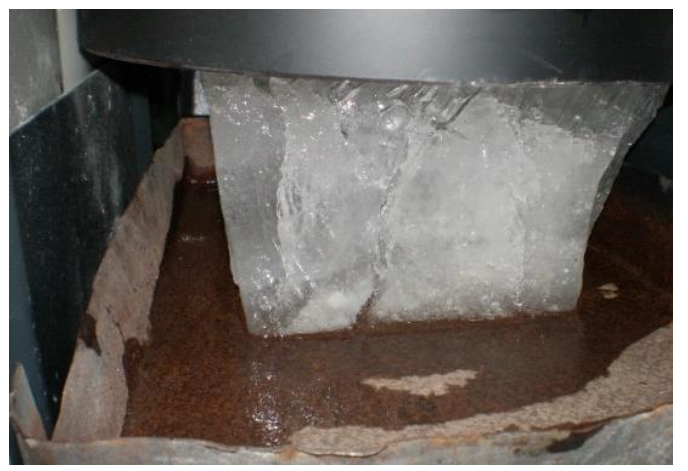

Fig. 1 Determination of the strength of an ice sample

The methodology presented in the literature for calculating ice loads determined by the strength tests of ice samples [1] has been determined by the specific dimensions and laboratory tests.

According to the CTR [1], the impact force of moving ice fields in contact with single pier with a vertical front edge of any shape is calculated in 2 cases (the lower value is taken for further calculations): when it is hit by single ice floes:

$$
F_{c, w}=0,07 v h_{d} \sqrt{A R_{c}}, \mathrm{MN}
$$

when ice collapses:

$$
F_{b, w}=0,5 R_{c} b h_{d}, \mathrm{MN}
$$

where: $h_{d}$ is calculated ice thickness, $\mathrm{m}$, is taken as follows: for rivers $-0.8 \mathrm{~m}$ at $1 \%$ probability; $R_{c}$ is standard compressive strength of ice MPa; $v$ is ice field movement velocity, $\mathrm{m} / \mathrm{s}$, determined on the basis of field investigations, and in their absence, as follows: for rivers and flood-exposed sea sections - keeping the flow rate constant; water reservoirs and seas - at a level equal to 0.03 wind velocity, determined during the drifting of the ice with a probability of $1 \% ; A$ is the area of the ice field, $\mathrm{m}^{2}$, determined on the basis of field investigations in the area under consideration or in the vicinity of the water body.

The impact force $F s, \mathrm{MN}$ of the stagnant ice field resting against structure and affected by flow and wind is calculated by the following equation:

$$
F_{s}=\left(p_{\mu}+p_{v}+p_{i}+p_{\mu, a}\right) A, \mathrm{MN},
$$

where: $p_{\mu}, p_{v}, p_{i}$ and $p_{\mu, \alpha}$ are the characteristic pressures, they are calculated according to the following equations:

$$
\begin{aligned}
& p_{\mu}=5 \cdot 10^{-6} v_{\text {max }}^{2}, \\
& p_{v}=5 \cdot 10^{-4} h_{d} v_{\text {max }}^{2} / L_{m}, \\
& p_{i}=9,2 \cdot 10^{-3} h_{d} i, \\
& p_{\mu, a}=2 \cdot 10^{-8} v_{w, \max }^{2},
\end{aligned}
$$

where: $v_{\max }$ is maximum $1 \%$ probability of water flow under the ice, $\mathrm{m} / \mathrm{s}$, during the drifting of the ice; $v_{w, \max }$ is maximum wind velocity of $1 \%$ probability, $\mathrm{m} / \mathrm{s}$, during the drifting of the ice; $L_{m}$ is average length of the ice field in the direction of flow, taken according to the data of field investigations; when not available, for rivers it is allowed to take $L_{m}=3 B_{r}$, where $B_{r}$ is river width, $\mathrm{m}$.

The force $F_{b, j}, \mathrm{MN}$, which is formed when pier cuts ice jam, is calculated according to the following equation:

$$
F_{b, j}=m b h_{j} R_{b, j}, \mathrm{MN},
$$

here: $m$ is the coefficient of the pier form in the plan; $b$ is width of the structure in the perpendicular direction of the flow at the level of ice impacts, $\mathrm{m} ; h_{j}$ is calculated thickness of the ice jam, determined by field investigations .It is possible to take $h_{j}$ according to the thermal regime of the ices in adjacent river sections, but not more than 0.8 in the mean flow depth during the drifting of the ice; $R_{b, j}$ is normative bearing strength of ice jam, MPa, determined by tests; if not available, $R_{b, j}=0,12 \mathrm{MPa}$;

The force $F_{s, j}, \mathrm{MN}$, formed due to the ice jam in the perpendicular contact with structure front, is calculated by the equation:

$$
F_{s, j}=l L_{j}\left(4 p_{\mu}+p_{v}+p_{i}+p_{\mu, a}\right), \mathrm{MN},
$$

where: $l$ is length of the structure strip at the level of ice jam operation; $L_{j}$ is length of ice jam strip; $L \approx 1,5 B_{r}$ (here $B_{r}$ is river width above the structure); $p_{\mu}, p_{v}, p_{i}$ and $p_{\mu, a}$ are ice pressures calculated according to Eqs. (4-7). Water flow velocity and the slope of the water surface are determined by field investigations.

The force $F_{b, i}, \mathrm{MN}$, by which the pier cuts ice jam, is calculated according to the equation:

$$
F_{b, i}=0,5 m R_{b, i} b h_{b, i}, \mathrm{MN},
$$

where: $m$ is coefficient of the pier form in the plan, $R_{b, i}$ is normative bearing strength of the ice jam; $R_{b, i}=0,25 \mathrm{MPa}$; $h_{b, i}$ is calculated ice jam thickness determined by field investigations.

\section{Results and discussion}

The results of the field investigations of the studied hydro systems piers with regard to the strength properties of concrete structures are given in Table 1. Structural strength is statistically evaluated (calculated variation coefficients of the samples, means of square deviation). The following table shows the location of the hydraulic structures, the year of research, the damage to the piers and the assessment of the technical state according to the Building Technical Regulation [10].

According to the performed studies, it was found that in very poor technical state are Antanavas (Marijampole district) and Kruostas (Kèdainiai district) spillway culverts piers - the reconstruction of these culverts is necessary. The lowest values of the compressive concrete strength are recorded in Marijampole HPP, where the technical state of the piers is evaluated as average. The most commonly observed damage is the decontamination of the protective concrete layer. The surfaces of investigated piers located in the 
changing level of water were more or less deteriorated by pittings. The deepest pitting $(26.8 \mathrm{~mm})$ was found in reinforced concrete structures of Marijampole Lagoon HS. Actual functioning period, average compression strength of concrete, average depth of the biggest pittings of investigated reinforced concrete structures and average deepening speed of pitting $v$ calculation results based on research data are given in Table 1.

Following laboratory tests with ice standard cubes $(15 \times 15 \times 15 \mathrm{~cm})$, the following 6 results were obtained: maximum destructive load (from 18.0 to $34.6 \mathrm{kN}$ ), strength (from 0.81 to $1.54 \mathrm{MPa}$ ) and sample up to fracture time (from 26.2 to $181.2 \mathrm{~s}$ ). By comparing the average compressive strength of 6 ice samples determined in the laboratory with the norms given in the CTR [1], it was determined that the ice generated in fresh water, at -15 degrees of air temperature, has a compressive strength of 0.85 to $1.2 \mathrm{MPa}$, i.e. equal to our already determined average ice compressive strength (from 0.81 to $1.54 \mathrm{MPa}$ ). According to the comparison it can be stated that the ice characteristics have been determined with sufficient accuracy.

Following the laboratory tests, the strength characteristics of the ice samples and the measurements of the piers of Antanavas HPP $(4 \times 1.5 \mathrm{~m}$ wide $)$, the following ice loads were calculated according to the equations given in the literature [1]: 1) the impact force of moving ice fields in contact with single pier; 2) the impact force of standing ice field, in the impact due to wind and water drag forces; 3) the force generated from ice jam cutting by pear; 4) the force of ice jam in the perpendicular contact with structure front; 5) the force, which is cutting pear of the ice plug.

Table 1

The data of the researched hydro systems' piers

\begin{tabular}{|c|c|c|c|c|c|c|c|c|c|}
\hline No. & $\begin{array}{l}\text { Name of } \\
\text { hydro- } \\
\text { power } \\
\text { plant } \\
\text { (HPP) }\end{array}$ & $\begin{array}{l}\text { Year of } \\
\text { research }\end{array}$ & $\begin{array}{l}\text { Average com- } \\
\text { pressive } \\
\text { strength of } \\
\text { concrete } f_{c m}, \\
\mathrm{MPa}\end{array}$ & $\begin{array}{c}\text { Variation } \\
\text { coefficient } \\
v, \%\end{array}$ & $\begin{array}{l}\text { Root-mean- } \\
\text { square devi- } \\
\quad \text { ation } \sigma\end{array}$ & $\begin{array}{l}\text { Depth } \\
\text { of pit- } \\
\text { ting, } \\
\text { mm }\end{array}$ & $\begin{array}{c}\text { Deepen- } \\
\text { ing speed } \\
\text { of pitting } \\
v, \text { mm per } \\
\text { year }\end{array}$ & $\begin{array}{l}\text { State of piers, } \\
\text { in points ac- } \\
\text { cording to the } \\
\text { CTR [10] }\end{array}$ & $\begin{array}{l}\text { Main deteriora- } \\
\text { tions }\end{array}$ \\
\hline \multicolumn{10}{|c|}{ Marijampolè municipality } \\
\hline \multirow{2}{*}{1} & \multirow{2}{*}{ Antanavas } & 1999 & 31.5 & 12.4 & 3.8 & 16.2 & 0.85 & 9.0 & \multirow{2}{*}{$\begin{array}{l}\text { Deep gullies, con- } \\
\text { crete deteriora- } \\
\text { tions, uncovered } \\
\text { reinforcement }\end{array}$} \\
\hline & & 2011 & $36.5^{*}$ & 9.3 & 5.2 & 7.1 & 1.01 & 9.0 & \\
\hline \multirow{2}{*}{2} & \multirow{2}{*}{$\begin{array}{l}\text { Marijam- } \\
\text { pole } \\
\text { Lagoon }\end{array}$} & 1999 & 13.5 & 29.1 & 6.6 & 26.8 & 1.41 & 2.0 & \multirow{2}{*}{$\begin{array}{c}\text { Deteriorated } \\
\text { protective layer }\end{array}$} \\
\hline & & 2009 & 12.7 & 22.5 & 5.3 & 15.3 & 1.70 & 2.0 & \\
\hline 3 & Pilviškiai & 2008 & $55.5^{*}$ & 4.6 & 2.7 & 9.1 & 0.91 & 4.0 & $\begin{array}{c}\text { Deteriorated } \\
\text { protective layer }\end{array}$ \\
\hline 4 & $\begin{array}{l}\text { Marijam- } \\
\text { polè city }\end{array}$ & 2009 & 25.0 & 21.8 & 9.5 & 13.2 & 1.47 & 2.0 & $\begin{array}{c}\text { Insignificant } \\
\text { deteriorations of } \\
\text { protective layer }\end{array}$ \\
\hline \multicolumn{10}{|c|}{ Kèdainiai district municipality } \\
\hline \multirow{2}{*}{5} & \multirow{2}{*}{ Kruostas } & 2005 & 33.9 & 9.9 & 3.7 & 12.4 & 0.95 & 9.0 & \multirow{2}{*}{$\begin{array}{c}\text { Deteriorated } \\
\text { protective layer, } \\
\text { gullies }\end{array}$} \\
\hline & & 2009 & 21.8 & 21.9 & 9.9 & 13.1 & 1.46 & 9.0 & \\
\hline \multirow{2}{*}{6} & \multirow{2}{*}{$\begin{array}{l}\text { Akademija } \\
\text { - Dotnuva }\end{array}$} & 2009 & 33.0 & 14.7 & 4.4 & 10.9 & 1.21 & 4.0 & \multirow{2}{*}{$\begin{array}{c}\text { Deteriorated } \\
\text { protective layer, } \\
\text { gullies }\end{array}$} \\
\hline & & 2011 & 32.5 & 14.5 & 4.3 & 9.1 & 1.30 & 4.0 & \\
\hline
\end{tabular}

Notations: $*$-reconstruction works

According to the performed studies, it was found that in very poor technical state there are Antanavas (Marijampole district) and Kruostas (Kèdainiai district) spillway culverts piers - the reconstruction of these culverts is necessary. The lowest values of the compressive concrete strength $(12.7 \mathrm{MPa})$ are recorded in Marijampole Lagoon HPP, where the technical state of the piers is evaluated as good. The most commonly observed damages are deterioration of the protective concrete layer.

Following the laboratory tests with standard ice cubes $(15 \times 15 \times 15 \mathrm{~cm})$, the results of 6 tests were as follows: maximum destructive load (from 18.0 to $34.6 \mathrm{kN}$ ), strength (from 0.81 to $1.54 \mathrm{MPa}$ ) and sample up to fracture time (from 26.2 to $181.2 \mathrm{~s}$ ). By comparing the average compressive strength of 6 ice samples determined in the laboratory with the norms given in the CTR [1], it was determined that the ice generated in fresh water, at - 15 degrees of air temperature, has a compressive strength of 0.85 to $1.2 \mathrm{MPa}$, i.e. equal to our average ice compressive strength (from 0.81 to $1.54 \mathrm{MPa}$ ). According to the comparison it can be stated that the ice characteristics have been determined with sufficient accuracy.

Following the laboratory tests, the strength characteristics of the ice samples and the measurements of the piers from Antanavas HPP $(4 \times 1.5 \mathrm{~m}$ wide) the following ice loads were calculated according to the equations given in the literature [1]: 1) the impact force of moving ice fields in contact with single pier; 2) the impact force of standing ice field, in the impact due to wind and water drag forces; 3 ) the force generated from ice jam cutting by pear; 4) the force of ice jam in the perpendicular contact with structure front; 5) the force, which is cutting pear of the ice plug. 
The impact force of moving ice fields in contact with single pier with any form of forward edge of the structure with a vertical leading edge calculated using equations (1) and (2) and adopted with a smaller one:

$$
F_{c, v}=153 \mathrm{kN}, F_{b, w}=180 \mathrm{kN} \text {. }
$$

The lowest is received calculating according to equation (2).

The impact of ice due to the temperature expansion of a continuous ice cover is calculated as a uniformly distributed load $q$, taking into account the ice thickness of $1 \%$ probability and the coefficient $k_{l}=0.6$, which is taken according to the ice cover width.

The impact force $F_{s}$, MN of standing ice field, in the impact due to wind and water drag forces is calculated according to equation (3):

$$
F_{s}=35.59 \mathrm{kN} \text {, }
$$

where: $p_{\mu}, p_{v}, p_{i}$ and $p_{\mu, \alpha}$ are characteristic pressures calculated according to equations (4)-(7): $p_{\mu}=0.000125 ; p_{v}=$ $0.000208 ; p_{i}=0.0000184 ; p_{\mu a}=0.0000045$.

The force $F_{b, j}$, MN, formed when pier cuts ice jam, is calcualted according to equation (8):

$$
F_{b, j}=27 \mathrm{kN} \text {. }
$$

The force $F_{s, j}, \mathrm{MN}$, generated from ice jam cutting by pear in the perpendicular contact with structure front, is calculated according to equation (9):

$$
F_{s, j}=94.49 \mathrm{kN} \text {. }
$$

The force $F_{b, i}, \mathrm{MN}$, which is cutting pier of the ice plug, is calculated according to equation (10):

$$
F_{b, i}=112.5 \mathrm{kN} \text {. }
$$

Field measurements of ice fields: $100 \mathrm{~m}^{2}$ area in Netičkampis hydro system, $200 \mathrm{~m}^{2}$ in the Marijampole city hydro system and $400 \mathrm{~m}^{2}$ in the Marijampole Lagoon hydro system. In order to evaluate the impact of the stagnant ice field loads on the vertical pier at a $45^{\circ}$ angle, load calculations were carried out in accordance with equation (3) for such kind of cases occurring in Lithuanian hydro systems.

With a constant ice thickness of $0.4 \mathrm{~m}$, but for various ice field areas $\left(100 \mathrm{~m}^{2}, 200 \mathrm{~m}^{2}, 400 \mathrm{~m}^{2}\right)$ and variable wind speeds $(5 \mathrm{~m} / \mathrm{s}$ and $10 \mathrm{~m} / \mathrm{s})$ as well as variable water flow velocity $(1 \mathrm{~m} / \mathrm{s}, 2 \mathrm{~m} / \mathrm{s}, 3 \mathrm{~m} / \mathrm{s})$, the following ice loads are calculated: 1) the impact force of moving ice fields in contact with single pier $F_{c, v} ; 2$ ) ice impact due to the temperature expansion of the continuous ice cover $q$; 3) the impact force $F_{s}$ of the standing ice field, in the impact due to wind and water drag forces; 4 ) the force by which the pier is cutting the ice jam $\left.F_{b, i} ; 5\right)$ the vertical force $F_{d}$ of the ice frozen on the structure, with the changing water level. The results of the calculations are presented in Table 2.

Based on the results of the ice loading calculations, Table 2 shows that the ice field area directly influences calculation results of the impact of moving ice fields in contact with single pier $F_{c, v}$, as well as the value of the load affected by the water flow velocity varies from $1 \mathrm{~m} / \mathrm{s}$ to $2 \mathrm{~m} / \mathrm{s}$. In the case of a change in flow velocity from $2 \mathrm{~m} / \mathrm{s}$ to $3 \mathrm{~m} / \mathrm{s}$ or a change in wind from $5 \mathrm{~m} / \mathrm{s}$ to $10 \mathrm{~m} / \mathrm{s}$, no significant influence on ice loads was observed.

Table 2

Results of calculations of ice loads taking into account the ice field area, water flow velocities and wind speeds

\begin{tabular}{|c|c|c|c|c|c|}
\hline \multirow{2}{*}{$\begin{array}{c}\text { Ice field } \\
\text { area, } \mathrm{m}^{2}\end{array}$} & \multicolumn{5}{|c|}{ Ice load type, $\mathrm{kN}$} \\
\cline { 2 - 6 } & $F_{c, v}$ & $q$ & $F_{s}$ & $F_{b, i}$ & $F_{d}$ \\
\hline $100^{1)}$ & 71.79 & 84 & 350.55 & 472.32 & 126.48 \\
\hline $200^{1)}$ & 101.53 & 84 & 350.55 & 472.32 & 126.48 \\
\hline $400^{1)}$ & 143.59 & 84 & 350.55 & 472.32 & 126.48 \\
\hline $100^{2)}$ & 143.59 & 84 & 350.55 & 472.32 & 126.48 \\
\hline $200^{2)}$ & 194.44 & 84 & 350.55 & 472.32 & 126.48 \\
\hline $400^{2)}$ & 194.44 & 84 & 350.55 & 472.32 & 126.48 \\
\hline $100^{3)}$ & 194.44 & 84 & 350.55 & 472.32 & 126.48 \\
\hline $200^{3)}$ & 194.44 & 84 & 350.55 & 472.32 & 126.48 \\
\hline $400^{3)}$ & 194.44 & 84 & 350.55 & 472.32 & 126.48 \\
\hline
\end{tabular}

Markings:

1) at wind speed of $5 \mathrm{~m} / \mathrm{s}$ and water flow velocity of $1 \mathrm{~m} / \mathrm{s}$; 2) at wind speed of $5 \mathrm{~m} / \mathrm{s}$ and water flow velocity of $2 \mathrm{~m} / \mathrm{s}$; 3 ) at wind speed of $5 \mathrm{~m} / \mathrm{s}$ and water flow velocity of $3 \mathrm{~m} / \mathrm{s}$. Note. In the case of wind speed of $10 \mathrm{~m} / \mathrm{s}$ and variable water flow velocity $(1 \mathrm{~m} / \mathrm{s}, 2 \mathrm{~m} / \mathrm{s}, 3 \mathrm{~m} / \mathrm{s})$, identical calculation results are obtained.

Table 3

Results of calculations of ice loads taking into account the thickness of ice

\begin{tabular}{|c|c|c|c|c|c|}
\hline \multirow{2}{*}{$\begin{array}{c}\text { Ice field } \\
\text { area, } \mathrm{m}^{2}\end{array}$} & \multicolumn{5}{|c|}{ Ice load type, $\mathrm{kN}$} \\
\cline { 2 - 6 } & $F_{c, v}$ & $q$ & $F_{s}$ & $F_{b, i}$ & $F_{d}$ \\
\hline $100^{1)}$ & 52.65 & 68.46 & 350.55 & 472.32 & 82.62 \\
\hline $200^{1)}$ & 74.46 & 68.46 & 350.55 & 472.32 & 82.62 \\
\hline $400^{1)}$ & 105.3 & 68.46 & 350.55 & 472.32 & 82.62 \\
\hline $100^{2)}$ & 143.59 & 84 & 350.55 & 472.32 & 126.48 \\
\hline $200^{2)}$ & 194.44 & 84 & 350.55 & 472.32 & 126.48 \\
\hline $400^{2)}$ & 194.44 & 84 & 350.55 & 472.32 & 126.48 \\
\hline $100^{3)}$ & 90.92 & 163.38 & 350.55 & 472.32 & 178.5 \\
\hline $200^{3)}$ & 128.58 & 163.38 & 350.55 & 472.32 & 178.5 \\
\hline $400^{3)}$ & 181.84 & 163.38 & 350.55 & 472.32 & 178.5 \\
\hline $100^{4)}$ & 112.33 & 189.84 & 350.55 & 472.32 & 238.68 \\
\hline $200^{4)}$ & 158.86 & 189.84 & 350.55 & 472.32 & 238.68 \\
\hline $400^{4)}$ & 224.66 & 189.84 & 350.55 & 472.32 & 238.68 \\
\hline
\end{tabular}

Markings:

1) ice thickness $0.3 \mathrm{~m}$;

2) ice thickness $0.4 \mathrm{~m}$;

3) ice thickness $0.5 \mathrm{~m}$;

4) ice thickness $0.6 \mathrm{~m}$. 
According to the results of the ice loading calculations presented in Table 3, ice thickness directly influences calculation results of the impact of moving ice fields in contact with single pier $F_{c, v}$, for the ice impact due to the temperature expansion $q$ of the continuous ice cover, to the vertical force $F_{d}$ of the ice frozen to the structure, when the water level changes.

The values for the temperature distribution of ice (0.4 $\mathrm{m}$ thick) for temperature expansion, calculated according to the normative documents of the United States [12], Canada [13], Finland [14], are the following: $q=51 \mathrm{kN} / \mathrm{m}$, $q=146 \mathrm{kN} / \mathrm{m}, q=178.9 \mathrm{kN} / \mathrm{m}$. These load values differ from the calculated ones according to the CTR [1], calculated at $q=84 \mathrm{kN}$.

Concrete-ice abrasion is a concrete surface degradation mechanism occurring due to ice-structure interaction [15]. According to the analysis of 6 hydropower plants reinforced concrete piers testing results (table 1) the strongest concrete with average compression strength $55.5 \mathrm{MPa}$ was established in the structures of Pilviskiai HPP (after reconstruction in 2007), the weakest one (12.7 MPa) was observed in the structures of Marijampole Lagoon HPP. The surfaces of structures made of weak concrete were damaged by ice abrasion much more.

The top speed of pitting deepening $(v=1.7 \mathrm{~mm}$ per year) was established in structures made of weak concrete $\left(f_{c}=12.7 \mathrm{MPa}\right)$ in Marijampole Lagoon HPP. The average deepening speed of pittings in the structures of Antanavas HPP was the smallest $-0.85 \mathrm{~mm}$ per year.

Established average deepening speed of a pitting in a structure $v$ (mm per year) - an average compression strength of concrete $f_{c}(\mathrm{MPa})$ relationship for investigated reinforced concrete piers shown in Fig.2.

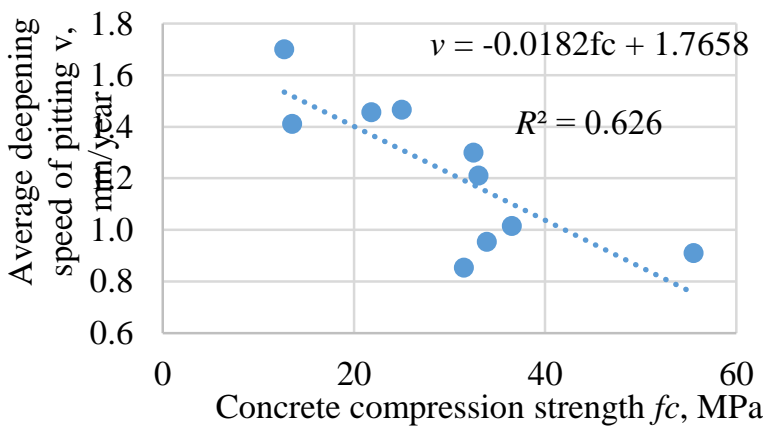

Fig. 2 The deepening speed of pittings - average compression strength of concrete relationship for reinforced concrete piers

Concrete compression strength's $f_{c}$ and average deepening speed of a pitting $v$ reliability of functional dependence were created. The established determination coefficients $R^{2}=0.626$, therefore it can be stated that examined strength parameters influence investigated average deepening speed of a pitting by $62.6 \%$, other part belongs to the influence of less important parameters. Using established linear dependence $v=-0.0182 f_{c}+1.7658$ for designed piers of HPP, which are on the changing water level, can be chosen concrete of such strength, that reinforcement of these structures won't uncover during foreseen time. The functional dependence of concrete compression strength's $f_{c}$ and average deepening speed of a pitting $v$ is quite similar for analytical expression of retaining walls concrete compression strength and average deepening speed of a pitting [16]:

$$
v=\frac{4.00}{f_{c}-5.28}
$$

where: $v$ is average deepening speed of pitting in structures, mm per year; $f_{c}$ is average compression strength of concrete, $\mathrm{MPa}$.

\section{Conclusions}

1. On the basis of carried out field investigations, it was found that spillway culverts piers are very damaged by ice and other loads in the areas of Antanavas (Marijampole district) and Kruostas (Kèdainiai district) - the reconstruction of these culverts is necessary. In other hydro systems, the most commonly are observed ice-inflicted damages, i.e. the deterioration of the protective concrete layer.

2. After laboratory tests with standard ice cubes $(15 \times 15 \times 15 \mathrm{~cm})$, their compressive strength was found to be between 0.81 and $1.54 \mathrm{MPa}$, which corresponds to the CTR [1] standard values of fresh water ice at the temperature of $15^{\circ} \mathrm{C}$.

3. Based on the results of the ice loading calculations, it has been determined that the ice field area directly influences the results of calculating the impact of moving ice fields (in contact with single pier $F_{c}, v$ ); as well as the size of this load is influenced by the speed of water flow, which varies from $1 \mathrm{~m} / \mathrm{s}$ to $2 \mathrm{~m} / \mathrm{s}$. In the case of a change in flow velocity from $2 \mathrm{~m} / \mathrm{s}$ to $3 \mathrm{~m} / \mathrm{s}$ or a change in the wind from $5 \mathrm{~m} / \mathrm{s}$ to $10 \mathrm{~m} / \mathrm{s}$, no significant impact on the results of the calculation of the ice loads has been noted.

4. Based on the results of the ice load calculations, it was found that the ice thickness directly influences the calculation results of the following ice loads: the impact forces of moving ice fields in contact with single pier $F_{c}, v$, the ice impact due to the temporal expansion of the ice cover $q$, the vertical forces $F_{d}$ of the ice frozen to the structure with varying water level.

5. The results of the calculations of the impact of ice on the temperature rise of the continuous ice cover $q$ according to the Lithuanian Construction Technical Regulation and the US, Canadian, Finnish normative documents vary up to 2 times.

6. The relationship of the average deepening speed of pittings caused by ice with average compressive strength of concrete has been taken according to developed analytical expression.

\section{References}

1. Construction Technical Regulation,STR 2.05.15:2004. Hydraulic structures impacts and loads. (in Lithuanian).

2. Timco, G. 1986. Indentation and penetration of edgeloaded fresh water ice sheets in brittle range. Offshore Mechanics and Arctic Engineering 109(3): 287-294. https://doi.org/10.1115/1.3257022.

3. Persson, S. 2015. Ice Impact Simulation for Propulsion Machinery, MTZ industrial 5: 34-41. https://doi.org/10.1007/s40353-015-0500-2.

4. Karna, T. 1994. Finite ice failure depth in penetration of a vertical indentor into an ice edge, Annals of Glaciology 19: 114-120.

https://doi.org/10.3189/1994AoG19-1-114-120.

5. Pernas-Sánchez, J.; Artero-Guerrero, J.A.; Varas, D.; López-Puente et al. 2015. Analysis of Ice Impact 
Process at High Velocity, Experimental Mechanics 55: 1669-1679.

https://doi.org/10.1007/s11340-015-0067-4.

6. Croasdale, K. R. 1984. The Limiting Driving Force Approach to Ice Loads, Offshore Technology Conference, Proc. of Offshore Technology Conference, pp. 57-64. https://doi.org/10.4043/4716-MS.

7. Daley, C.; Tuhkuri, J.; Riska, K. 1998.The role of discrete failures in local ice loads Cold Regions Science and Technology 27(3):197-211. https://doi.org/ 10.1016/S0165-232X(98)00007-X.

8. Šadzevičius, R. 2005. Modelling and Analysis of Environmental Impact on Reinforced Concrete Slabs for Earth Dam Slope Protection: Doctoral Dissertation, Kaunas. Akademija: Publishing Center of Lithuanian University of Agriculture, 130 p. (in Lithuanian).

9. Belozaras, E. 2009. Influence of Ice Load on the Reinforced Concrete Slabs of Strengthening Slopes: Master's Thesis. Aleksandras Stulginskis University, 72 p. (in Lithuanian). eLABa ID: 2087589.

10. Construction Technical Regulation, STR.1.07.03:2017, Technical and maintenance supervision of structures, Order of formation of new real estate cadaster objects. (in Lithuanian).

11. European Standard, EN 12504-2:2012, Testing concrete in structures, Part 2: Non-destructive testing, Determination of rebound number. Available from Internet: https://www.en-standard.eu.

12. EM 1110-2-2200.58, US Army Corps of Engineers, Engineering and Design, Gravity Dam Design. Available from Internet: http://www.publications.usace.army.mil /Portals/76/Publications/EngineerManuals/EM_1110-22200.pdf?ver=2013-09-04-070817-750.

13. EM 1110-2-1612.99, Ice forces on structures. Available from Internet: http://www.publications.usace.army.mil/ Portals/76/Publications/EngineerManuals/EM_1110-21612.pdf?ver=2013-09-04-102248-027.

Fransson, L. 1988. Thermal ice pressure on structures in ice covers, Doctoral thesis, Lulea University of technology, 161 p. Available from Internet: https://www.diva-portal.org/smash/get/diva2:990630/FULLTEXT01.pdf

14. Shamsutdinova, G.; Hendriks, A.N.; Jacobsen, S. 2017. Concrete-Ice Abrasion Laboratory Experiments,
Proceedings of the 24th International Conference on Port and Ocean Engineering under Arctic Conditions June 11-16, 2017, Busan, Korea

15. Vaisvila, K.A.; Lindisas, L.; Sadzevicius, R. 2002. The research of deterioration of reinforced concrete structures functioning in the changing level of water engineering constructions, Water management engineering: transactions, Kaunas-Akademija: Vilainiai 18(40): 47-52.

\section{R. Šadzevičius, T. Sankauskienè}

\section{ICE LOADS IMPACT ON SPILLWAY CULVERTS PIERS IN LITHUANIA}

S u m m a r y

On the basis of literature analysis and field investigations it was found that piers in spillway culverts suffer most from the ice impacts. Floating ice is a significant hazard to structures - jamming between piers or rubble pile development will modify the effective size of the structure and possibly increase the loads. Ice loads are generally described as ice forces or pressures acting over an area of structure. Ice loads are classified as: static loads, dynamic loads, global loads, local loads. Local ice loads from ice-structure interaction are highly irregular and very hard to model exact. The aim of this work - to evaluate ice loads formed in the ponds of Lithuania and their impact on the spillway culverts piers structures. The ice loads were analysed in this work: 1) the force of moving ice fields in contact with single pier; 2) the force of standing ice field, in the impact due wind and water drag forces; 3 ) the force from ice jam cutting by pier; 4) the force of ice jam in the perpendicular contact with structure front, 5) the force, which is cutting pier of the ice plug.

Keywords: ice load, spillway culvert piers, impact.

Received April 20, 2018 Accepted June 25, 2018 